\title{
Multicultural Value in the Traditional Islamic Boarding School, Bina Insan Mulia (BIMA), Cirebon, Indonesia
}

\author{
Ety Nurhayati \\ IAIN Syekh Nurjati Cirebon \\ etinurhayati@syekhnurjati.ac.id \\ Yayah Nurhidayah \\ IAIN Syekh Nurjati Cirebon \\ yayahnurhidayah@syekhnurjati.ac.id
}

\begin{abstract}
Multicultural Education in Islamic Boarding Schools teaches tolerance and openness in carrying out activities of daily living. This research was conducted at the Bina Insan Mulia (BIMA) boarding school using descriptive qualitative methods, as well as data collection techniques by interviewing, observing, documenting studies, and FGDs. The conclusions of this study are: (1) The values of Multicultural Islamic Education implemented at the BIMA Islamic Boarding School are sourced from books / books taught to students / students such as the book of Hadith al-Arba'in Nawawiyah, Safinah al-Najah, Fath alQarib , Ta'lim al-Mutaa'llim, Taysir al-Khalaq, and Riyadh al-Saliheen; (2) The application of multicultural values includes openness, humanity, tolerance, mutual assistance, justice, equality, brotherhood.
\end{abstract}

Keywords: Islamic Education; multicultural; multicultural values; book.

\begin{abstract}
Abstrak
Pendidikan Multikultural di Pondok pesantren mengajarkan toleransi dan keterbukaan dalam melaksanakan aktifitas hidup sehari-hari. Penelitian ini dilakukan di pondok pesantren Bina Insan Mulia (BIMA) dengan menggunakan metode deskriptif kualitatif, serta teknik pengumpulan data dengan wawancara, observasi, studi dokumentasi, dan FGD. Kesimpulan penelitian ini adalah: (1) Nilai-nilai Pendidikan Islam Multikultural yang diterapkan di Pondok pesantren BIMA bersumber dari kitab / buku yang diajarkan kepada murid / Santri seperti kitab Hadits al-Arba'in Nawawiyah, Safinah al-Najah, Fath al-Qarib, Ta'lim al-Mutaa'llim, Taysir al-Khalaq, dan Riyadh al-Shalihin; (2) Penerapan nilai-nilai multikultural tersebut meliputi keterbukaan, kemanusiaan, toleransi, saling membantu, keadilan, kesetaraan, persaudaraan.

Kata kunci: Pendidikan Islam; multikultural; nilai-nilai multikultural; kitab.
\end{abstract}

ISSN 1979-1739 (P) ; ISSN 2502-8057 (E).

(c) 2019 Nadw a : Jurnal Pendidikan Islam | UN Walisongo.

Accredited by Ristekdikti based on Decree No. $51 / E / K P T / 2017$

http://journal.walisongoac.id/index.php/nadwa 


\section{Introduction}

Pondok pesantren are functioned as a developer and maintainer of the teaching of Islamic orthodoxy. A wide range of beliefs, norms, and Islamic values are transmitted through a variety of instructional activities, formally and informally. Religious teachings are develops normative, symbolic, and sometimes, less responsive to the community development on the outside. For example, gender equality and multiculturalism are foreign issues in pondok pesantren. This is often reinforced by the teachings presented by Kyai and Nyai in various forms of study, treatment, and the practice of everyday life to the Santri in the area of pondok pesantren that are still bias in gender.

Life in pondok pesantren generally still holds traditional culture, where the pattern of communication still hierarchical between Santri and Kyai, or between Ustadz/Ustadzah (teachers) and their Santri. The regulations that applied to the Santri generally top-down and even apply heavy sanctions if violates the rules. Kitabs that are taught generally use classic still bias in gender. Such culture then internalized by Santri and stored in their subconscious memory, so have the bias mindset that manifest in insights, attitudes, and behavior. When already become a mindset, it would be potentially causing a conflict when socializing with different cultures.

Even so, not all boarding schools have the same condition. Some modern Islamic Boarding School in Indonesia, for example: Gontor in East Java and several of its branches and across Indonesia, Al-Salam in Solo, and others, have been accommodating to contemporary developments, engage in various other fields in multidimensional with developments outside of boarding schools.

Some opinions about the existence, characteristics, and traditions of life in boarding schools has been widely described by the experts. According to Mujammil Qomar, boarding schools are often identified have three important roles in society, namely the Indonesia Center for the transmission of traditional Islamic 
sciences, keeping the continuity of traditional Islam, and reproduction of the 'ulama1.

Although pondok pesantren have many contributions in building the nation mental, but some education observers much criticized it. Abdullah Ali stated that Islamic education during this time has a lot of practicing the educational process which are exclusive and dogmatic. These educational process as it generally happens at the madrasah, Islamic schools, and boarding schools2. Amin Abdullah criticized that the process and instruction of education in pondok pesantren generally emphasize the salvation of individual and his group than the salvation of others outside the group3. Abdul Munir Mulkhan mentioned the weakness of the Islamic Education include: (1) the limited space of the difference of opinion between teachers with students, or between one student with other students and the learning process are indoctrinative; (2) The educational focus only on achieving the capabilities of ritual and tauhid belief, and singular material namely true-false and good-bad that is mechanistic4. According to Abdurrahman Mas'ud, an indicator of the weakness of Islamic education that is both exclusive and indoctrinative due to: (1) The teacher more frequently advised students in a threatening way; (2) Teachers more often pursue standard academic value, so little regard for aspects of morality or student manners; (3) The intellectual intelligence of students are not balanced with social sensitivity and spirituality of religion5. Although this is closer to criticism in formal schools, the consideration of researchers raises

1Mujammil Qomar. Pesantren: Dari Transformasi Metodologi Menuju Demokratisasi Institusi. (Jakarta: Erlangga, 2009), 75.

2Abdullah Ali. Pendidikan Islam Multikultural di Pesantren. (Yogyakarta: Pustaka Pelajar, 2011), 3.

3Amin Abdullah. "Pengajaran Kalam dan Teologi di Era Kemajemukan: Sebuah Tinjauan Materi dan Metode Pendidikan Agama”. Jurnal Taswir elAfkar. (Edisi 1 No 2, 2011), 11.

4Abdul Munir Mulkhan."Humanisasi Pendidikan Islam". Jurnal Tashwir el-Afkar. (Edisi 1 No 2, 2011), 17-18.

5Abdurrahman Mas'ud. Format Baru Pola Pendidikan Keagamaan pada Masyarakat Multikultural dalam Perspektif SISDIKNAS. (Semarang: Aneka Ilmu, 2004), 87. 
here to appear as a comparison of the formal school education process and boarding school.

Therefore, a model of Islamic education in Indonesia that monocultural is not appropriate with the Indonesia community that plural and multicultural, in accordance with the mandate of Van Indonesia No.20/ 2003 about the System of National Education that accommodate the values of human rights and multicultural spirit, even described that: "Education was held in a democratic and equitable and not discriminatory, with the upholding of human rights, cultural values, religious values, and the pluralization of the nation"6. Therefore, it is proper for Islamic education institutions to perform the transformation from mono cultural paradigm to multicultural paradigm.

The term multicultural is always associated with education, so it has a broad meaning any set of processes by which schools work rather than against oppressed groups. The term used for Multicultural Education in several countries has differences, for example: interethnic education, transcultural education, multiethnic education, cross-cultural education, human rights education, intercultural education, or inclusive education. Multicultural Education is learning that is free from racism, sexism, and other forms of social domination and intolerance7. Everyone must be treated fairly and empowered. There is no dominance of minority groups, both due to skin color, religion, gender, social status, and other attributes and characteristics.

According to the Islamic perspective, cultural differences are circumcisions. Multicultural Education opens awareness of the world of education "how to address differences with tolerant and egalitarian attitudes"8.

Multicultural Education is widely recognize, respect, and accommodate the diversity of gender, ethnicity, culture, race, social strata, religious schools, and religion. Multicultural

6Undang-Undang RI No 20/2003 Sistem Pendidikan Nasional. (Jakarta: Cemerlang, 2003), Bab III Pasal 4 Ayat 1.

7Abdullah Ali. Pendidikan Islam Multikultural di Pesantren. (Yogyakarta: Pustaka Pelajar, 2011), 103,107.

${ }_{8}$ Choirul Mahfud. Pendidikan Multikultural. (Yogyakarta: Pustaka Pelajar, 2006), 168). 
education aims to liberate people from ignorance, poverty, underdevelopment, inequality as a result of the bottom-up hierarchical partnership, dominance-subordination, superiorinferior, oppressive-oppressed in the relationship of religious, ethnic, cultural, and gender. Bina Insan Mulia (BIMA) Pondok pesantren in Cirebon - West Java, which chosen as the object of this research, as it has implemented the Multicultural Islamic Education.

Multicultural Education is very urgent, can even be given to students as early as possible, especially in the current global era, in which the limits of world culture is getting thin, so some institutions have implemented Multicultural Education.

\section{Method}

Based on the content fields, this research used two approaches are Islamic Education and Multicultural Education. The data obtained from the field research and library research.

This research used qualitative descriptive method, which the results of the research will be presented in the form of a narrative description. This research is descriptive research pertained to the qualitative, due to the nature of the data collected in the form of conditions of social reality are observed and analyzed in a descriptive narrative, and not the shape of the data that can be quantified with numbers, both the data collected in earlier surveys, during the process of the research, as well as analysis and the results' reports of research.

The main respondents of research are Kyai and ustadz/ustadzah as primary, and the respondent santriwan (male student) and santriwati (female student) represent the purposive from each level as the advocates respondent. The research data collection using four techniques: interviews, observation, documentation, and focus group discussion (FGD). There are some steps taken in analyzing the research data: (1) collecting data, (2) performing data reduction, (3) doing the display data, (4) verification of the data, and (5) the deduction. 


\section{The Implementation of Multicultural Islamic Education}

Multicultural Islamic Education implemented in the BIMA pondok pesantren can be examined from emergence and material of methods. The learning method applying andragogy method, which Santri should treated to be a self-sufficient man in all things, both to maintain the necessities of life or way of learning that suits of each their learning style and feel appropriate and comfortable. The task of the teacher as a facilitator and supervisor of learning. The material taught is limited according to their interest to continue the studies, and target of study is in accordance with the interests and goals of the future to develop a specific science. The institutions only provide and serve the lessons that require and support on their future goals. The curriculum of pondok pesantren includes six categories: (1) Appropriate subjects of UN (Ujian Nasional); (2) Classical kitabs; (3) Tahfidz Qur'an; (4) Foreign language; (5) Arts, culture, and sports according to their interests; (6) Multicultural insights and actual issues of Kyai directly to the Santri and Teachers.

In the current global era, in almost all parts of the world, the social reality of its citizens is multicultural, caused by bilateral or multilateral diplomatic relations between countries, both in the fields of economy, education, social, religion, culture, and politics. According to Berry et al, that multiculturalism basically aims to create a sociopolitical context that allows individuals to develop healthy identities and reciprocally develop positive attitudes among groups9. The development of multicultural ideologies, attitudes and policies can be a reliable solution in an effort to create a just society, integrate with shared values that value the diversity of the social and political ideal of the togetherness in difference culture 10 .

The term multiculturalism has different meanings in the context of Sociology, political philosophy, and daily use. In Sociology and daily use, the word is synonymous with ethnic pluralism, where the two terms are often used interchangeably.

${ }_{9}$ John W. Berry. et al. Psikologi Lintas Budaya: Riset dan Aplikasi. (Jakarta: Gramedia, 1999), 577-580.

10Iris Morion Young. Justice and the Politics of Difference. (New Jersey: Princenton University Press, 1990), 175. 
For example, a cultural pluralism, in which various ethnic groups collaborate and are able to dialogue with one another without having to sacrifice their particular identity. Multicultural education is very important given to the Santri so that they grow a sense of solidarity and social care for others who are different in gender, social class, race, and ethnicity, as stated by Banks \& Banks as follows:

Multicultural education incorporates the idea that all students regardless of their gender, social class, and ethnic, racial, or cultural characteristics should have an equal opportunity to learn in school. Another important idea in multicultural education is that some students, because of these characteristics, have a better chance to learn in schools as they are currently structured than do students who belong to others groups or who have different cultural characteristics. Multicultural education is also a reform movement that is trying to change the schools and other educational institutions so that students from all social-class, gender, racial, language, and cultural groups will have an equal opportunity to learn. Multicultural education involves changes in the total school or educational environment, it is not limited to curricular changes 11 .

The definition of Multicultural Education explained by experts with different sentences. According to Bikhu Parekh12, Multicultural Education is an education in freedom, both in the sense of freedom from ethnocentric prejudices and biases, and freedom to explore and learn from other cultures and perspectives. Almost the same definition is explained by Banks \& Banks as follows:

Multicultural education is an idea, an educational reform movement, and a process whose major goal is to change the structure of educational institutions so that male and female students, exceptional students, and students who are members of diverse racial, ethnic, language, and cultural groups will have an equal chance to achieve academically in school. It is necessary to

11James A, Banks, \& Cherry A Mc Gee Banks. Multicultural Education: Issues and Perspective. (University of Washington: Wiley, 2010), 3.

12Bikhu Parekh. Rethinking Multiculturalism: Cultural Diversity and Political Theory. (Cambridge: Harvard University Press, 2000), 230. 
conceptualize the school as a social system in order to implement multicultural education successfully. Each major variable in the school, such as- its culture, its power relationships, the curriculum and materials, and the attitudes and beliefs of the staff-must be changed in ways that will allow the school to promote educational equality for students from diverse groups. To transform the schools, educators must be knowledgeable about the influence of particular groups on student behavior13.

\section{The Kind of Kitabs}

Based on studies in the field it is known that the kitab taught to Santri are: (1) Hadith Arba'in el-Nawawiyah, (2) Safinah alNajah, (3) Fath el-Qarib, (4) Ta'lim al-Mutaalim, (5) Taysir alKhalaq fi Ilm al-Akhlaq, and (6) Riyadh al-Shalihin.

According to Zamakhsyari Dhofier14, kitabs in the pondok pesantren can be classified into eight clasifications: Nahwu sharaf, Fiqh-Ushul Fiqh, Hadits, Tafsir, Tauhid, Tasawuf, Tarikh, and Balaghah. Nurcholis Madjid15 classified into four:

$\checkmark$ Fiqh: Shafinah el-shalah, Shafinah el-Najah, Fath el-Qorib, Taqrib, Fath el-Mu'in, Minhaj el-Qawim, Muthma'innah, elIqna', Fath el-Wahab.

$\checkmark$ Tauhid: Aqidah el-Awwam, Bad'el-Amal, Sanusiyah.

$\checkmark$ Tasawuf: El-Nasha'ih el-Diniyah, Irsyad el-Ibad, Tanbih elGhafilin, Minhaj el-Abidin, el-Da'wah el-Tammah, el-Hikam, Risalah el-Mua'wanah wa el-Muzhaharoh, Bidayah elHidayah.

$\checkmark$ Arabic: El-Maqsud, Awamil, Imriti, el-Jurumiyah, Kaylani, Mirhah el-I'rab, Alfiyah, Ibn Aqil.

Steenbrink 16 in his study classified the kitabs taught in the pondok pesantren into five classifications below:

13James A, Banks, \& Cherry A Mc Gee Banks. Multicultural Education: Issues and Perspective. (University of Washington: Wiley, 2010), 1.

14Zamakhsyari Dhofier. Tradisi Pesantren: Studi tentang Pandangan Hidup Kyai. (Jakarta: LP3ES, 1994), 50.

${ }_{15}$ Nurcholis Madjid. Bilik-Bilik Pesantren. (Jakarta: Paramadina, 1997),

16Karel A. Steenbrink. Pesantren, Madrasah, Sekolah: Pendidikan Islam dalam Kurun Modern. (Jakarta: LP3ES, 1986). 
$\checkmark$ Fiqh: Safinah el-Najah, Sulam el-Taufiq, Masail el-Sittin, Mukhtashar, Minhaj el-Qowim, el-Hawasyi el-Madaniyah, el-Risalah, Fath el-Qorib, el-Iqna, Tuhfat el-Habib, elMuharrar, Minhaj el-Thalibin, Fath el-Wahab, Tuhfat elMuhtaj, Fath-el-Muin.

$\checkmark$ Arabic: Muqaddimah el-Jurumiyah, Mutammimah, elFawaaqih el-Janniyah, el-Durrah-el Bahiyah, el-Awamil elMi'at, Inna Awla, Alfiyah, Minhaj el-Masalik, Tamrin elTullah, el-Rafiyyah, Qathr el-Nada, Mujib el-Nida, elMisbah.

$\checkmark \quad$ Ushul el-Din: Bahjat el--Ulum, Umm el-Barahin, el-Mufid, Fath el-Mubin, Kifayat el-Awwam, el- Miftah- fi syarh Ma'rifat el-Islam, Jawharah el-Tauhid.

$\checkmark$ Tasawuf: Ihya el-Ulum el-Din, Bidayah el-Hidayah, Minhaj -el-Abidin, el-Hikam, Sua'b al-Iman, Hidayat el-Azkiya, 'Ila Thariq el-Awliya.

$\checkmark$ Tafsir: Tafsir el-Jalalain.

In its present reality, the kitabs that are scattered and used in pondok pesantren has not been spelled out and varied, depending on the interests and background of Kyai as the authority.

\section{The Content of Multicultural Islamic Education Values}

To analyze the presence or absence of multicultural values in the kitabs taught, used the indicators seven standard: openness, deliberation or discussion, humanity, tolerance, mutual helping, justice, equality, and brotherhood. Based on these indicators, the multicultural values contained in these kitabs are briefly described as follows:

Table

The Multicultural Values in the Kitabs

\begin{tabular}{|c|c|c|c|}
\hline No. & Kitabs' Name & $\begin{array}{c}\text { Multicultural } \\
\text { Values }\end{array}$ & Found in the Chapter \\
\hline 1. & Hadith & $\begin{array}{l}\text { Explicit content } \\
\text { of multicultural } \\
\text { values: } \\
\text { 1. Humanity } \\
\text { 2. Tolerance }\end{array}$ & $\begin{array}{l}\text { Leaving unwholesome, } \\
\text { loving fellow Muslims, } \\
\text { saying good or silent, do } \\
\text { not be angry, do good in } \\
\text { all matters, have shame, }\end{array}$ \\
\hline
\end{tabular}




\begin{tabular}{|c|c|c|c|}
\hline & Arbain17 & $\begin{array}{l}\text { 3. Mutual } \\
\text { helping } \\
\text { 4. Justice } \\
\text { 5. Equality, } \\
\text { brotherhood }\end{array}$ & $\begin{array}{l}\text { prohibit acts of } \\
\text { wrongdoing, give alms } \\
\text { from excess assets, stay } \\
\text { away from disturbing } \\
\text { actions, do not do } \\
\text { damage, accuser must } \\
\text { bring proof, must not be } \\
\text { mutual envy, must help } \\
\text { the difficulties of fellow } \\
\text { Muslims, and must bow } \\
\text { down to lust. }\end{array}$ \\
\hline 2. & $\begin{array}{l}\text { Safinat } \\
\text { Najah } 18\end{array}$ & $\begin{array}{l}\text { Implicit content } \\
\text { of multicultural } \\
\text { values: } \\
\text { 1. Humanity } \\
\text { 2. Tolerance } \\
\text { 3. Mutual } \\
\text { helping Equality, } \\
\text { 4. brotherhood }\end{array}$ & $\begin{array}{cr}\text { Praying, fasting, alms, } \\
\text { remains, } \\
\text { pilgrimage }\end{array}$ \\
\hline 3. & Fath el-Qarib19 & $\begin{array}{l}\text { Implicit content } \\
\text { of multicultural } \\
\text { values: } \\
\text { 1. Humanity } \\
\text { 2. Tolerance } \\
\text { 3. Mutual } \\
\text { helping Equality, } \\
\text { 4. brotherhood }\end{array}$ & $\begin{array}{l}\text { Praying, fasting, alms, } \\
\text { remains, and pilgrimage, } \\
\text { muamalat (buying and } \\
\text { selling, inheritance, and } \\
\text { will) }\end{array}$ \\
\hline 4. & $\begin{array}{l}\text { Ta'lim al- } \\
\text { Muta'allim } 20\end{array}$ & $\begin{array}{l}\text { Explicit content } \\
\text { of multicultural } \\
\text { values: } \\
\text { 1. Deliberation or } \\
\text { discussion } \\
\text { 2. Justice } \\
\text { 3. Mutual } \\
\text { helping }\end{array}$ & Deliberation or discussion \\
\hline
\end{tabular}

${ }_{17}$ Abu Zakaria Yahya bin Syaraf Bin Murri el-Nizami el-Nawawi elBantani. Hadith el-Arbain el- Nawawi. (Jakarta: Daar el- Haq). Najah.

${ }_{18}$ Syeikh Salim bin Sumair Al Hadhramy. (nothing year). Safinat el-

19Al-Qadhi Abu Syuja' Ahmad bin Husain bin Ahmad al-Asfahani (nothing year). Fath el-Qarib.

20Al- Zarnuji. Ta'lim Muta'alim. (Surabaya: Mutiara Ilmu, 2009). 


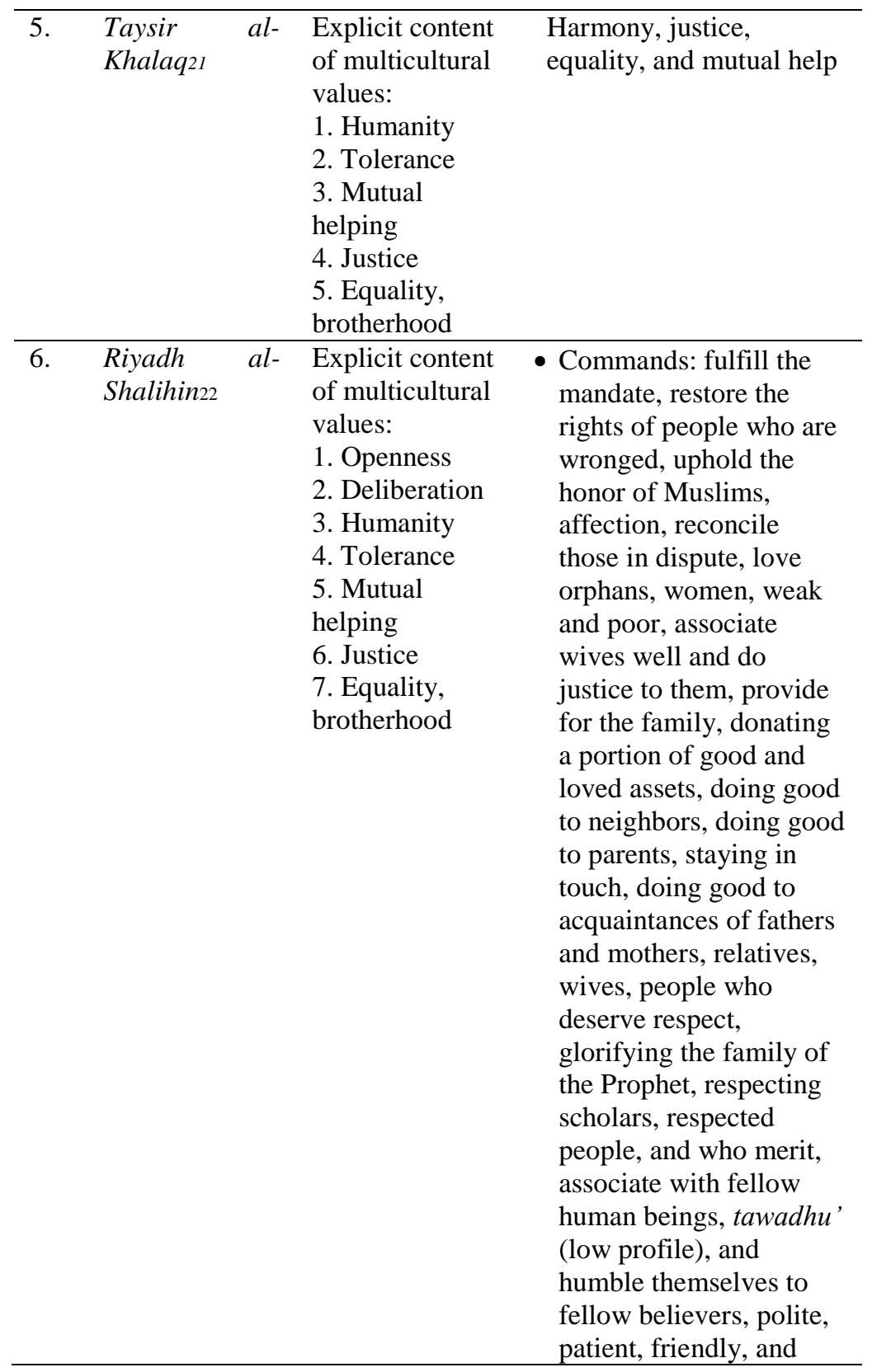

21Al-Hafidz Hasan al-Masdudi. Taysir el-Khalaq fi Ilm el-Akhlaq. (Surabaya: Mutiara Ilmu, 2016).

22Abu Zakaria Muhyidin al-Nawawi. (nothing year). Riyadh el-Shalihin. 


\begin{tabular}{ll}
\hline & forgiving, the leader \\
& must be fair, be gentle, \\
& affection, give advice, \\
& do not cheat, do benefit \\
& and prioritize the \\
& interests of its people, \\
& Prohibition: do \\
& wrongdoing, eat the \\
& wealth of orphans, open \\
& the secrets of Muslims, \\
& disobedience to parents, \\
& break brotherhood, \\
& arrogant, wasteful, hurt \\
& righteous people, weak, \\
& and poor, complain, lie, \\
& become false witnesses, \\
& hate and decide rope of \\
& friendship, berating, \\
& envy, cursing, \\
& gossiping and hearing \\
& gossip, getting worse, \\
disturbing and hurting & others, insulting \\
Muslims, insulting \\
descendant, cheating, \\
betraying fellow \\
Muslims for more than \\
three days, whispering \\
in front of others, \\
usury, riya', forgiving \\
Muslims, suspending \\
paying debts, and \\
hypocrites. \\
\hline
\end{tabular}

Every individual in the eyes of Allah is the same, except the difference is the level of devotion. This is the moral message of multicultural values explicitly and implicitly contained in these kitabs. The purpose of implementing Multicultural Education in pondok pesantren is to be a generation that able to uphold morality, discipline, social care, and honesty in daily behavior. According to Abdullah, the values of Multicultural Education include: democracy, equality, justice, humanity, togetherness, 
peace, acknowledging differences, accepting differences, and respecting differences23. Thus, all attitudes that will be painful, troublesome, detrimental, and damage the relationship between someone and others are prohibited, despite different religions, customs, races, sexes, characters, and social status. In Multicultural Education, the instilled values are a way of life that respects, sincerely, and tolerant to the diversity of a pluralistic culture of society.

\section{Conclusions}

The purpose of implementing Multicultural Education in pondok pesantren is to be a generation that able to uphold morality, discipline, social care, and honesty in daily behavior Multicultural Islamic Education has been implemented in the BIMA Islamic boarding school through the religious books (Kitab-kitab) studied.The kitabs taught to Santri are Hadith elArba'in el-Nawawiyah, Safinat el-Najah, Fath el-Qarib, Ta'lim el-Mutaalim, Taysir el-Khalaq fi Ilm-el-Akhlaq, and Riyadh alShalihin. The values of multicultural in these kitabs are openness, deliberation, humanity, tolerance, mutual helping, justice, equality and brotherhood, which are found in the chapters that are explosively and implicitly mentioned.

\section{References}

Abdullah. Amin, "Pengajaran Kalam dan Teologi di Era Kemajemukan: Sebuah Tinjauan Materi dan Metode Pendidikan Agama". Jurnal Taswir el-Afkar. Edisi 1 No 2. 2011.

Abdullah, Jihan. "Pendidikan Islam Multikultural di Pesantren: Studi Kasus Pondok pesantren Modern Gontor Poso". Istiqra. Jakarta: Jurnal Penelitian lmiah, ISSN:2338025x, Vol.2 No 1, Januari -Juni 2014

Al- Zarnuji, Syekh Burhanuddin. Ta'lim Muta'alim. Surabaya:

23Abdullah Ali. Pendidikan Islam Multikultural di Pesantren. (Yogyakarta: Pustaka Pelajar, 2011), 109. 
Mutiara Ilmu. 2009.

Al-Asfahany, al-Qadhi Abu Syuja'bin Ahmad bin Husain bin Ahmad. nothing year. Fath el-Qarib.

Al-Bantani, Abu Zakariya Yahya bin Syaraf Bin Murri el-Nizami el-Nawawi. nothing year. Hadith el-Arbain el-Nawawi.

Al-Hadhrami, Syekh Salim Sumair bin Abdullah bin Saad. no year. Safinat el-Najah. Surabaya: Mutiara Ilmu.

Ali, Abdullah. Pendidikan Islam Multikultural di Pesantren. Yogjakarta: Pustaka Pelajar. 2011.

Al-Masdudi, al-Hafidz Hasan. Taysirul Khalaq fi Ilm el-Akhlaq. Surabaya: Maktabah Ahmad Nabhan. 2016.

Al-Nawawi, Abu Zakaria Muhyidin. nothing year. Riyadh alShalihin.

Dhofier, Zamakhsyari. Tradisi Pesantren: Studi tentang Pandangan Hidup Kyai. Jakarta: LP3ES. 1982.

James A, Banks, \& Cherry A Mc Gee Banks. Multicultural Education: Issues and Perspective. (University of Washington: Wiley. 2010.

John W. Berry. et al. Psikologi Lintas Budaya: Riset dan Aplikasi. (Jakarta: Gramedia. 1999.

Madjid, Nurcholis. Bilik-Bilik Pesantren, Jakarta: Paramadina. 1997.

Mulkhan, Abdul Munir. 2011. "Humanisasi Pendidikan Islam". Jurnal Tashwir el-Afkar. Edisi 1 No 2.

Parekh, Bikhu. 2000. Rethinking Multiculturalism: Cultural Diversity and Political Theory Cambridge: Harvard University Press.

Qomar, Mujamil. 2009. Pesantren: Dari Transformasi Metodologi Menuju Demokratisasi Institusi. Jakarta: Erlangga.

Steenbrink, Karel, A. 1986. Pesantren, Madrasah, Sekolah: Pendidikan Islam dalam Kurun Modern. Jakarta: LP3ES Undang-Undang Republik Indonesia No 20/2003 Sistem Pendidikan Nasional. (2003). Jakarta: Cemerlang.

Young, Iris Marion. 1990. Justice and the Politics of Difference. New Jersey: Princenton University Press. 